\title{
CANVAS MODEL INNOVATION ON DELIVERY CONTROL
}

\author{
Retty Dwi Handayani ${ }^{1}$ \\ Diah Suryaningtyas ${ }^{2}$ \\ Tofa Apriansyah ${ }^{3}$ \\ ${ }^{1,2}$ The Indonesian FDA Jakarta Regional Office, East Jakarta \\ ${ }^{3}$ Center of Drug and Food Studies, The Indonesian FDA, Central Jakarta \\ Email: retty.handayani@pom.go.id \\ Email: apriansyahtf@gmail.com
}

\section{ARTICLE INFORMATION}

Received date

[30-09-2020]

Revision

[21-12-2020]

Accepted date

[22-12-2020]

\begin{abstract}
:
The illicit trade, especially for drug and food, has risen due to shifting in information technology and lifestyle. Various data compiled from the Pangea Operation showed an increase of illicit drugs and food sold online within 2015-2018; meanwhile estimated $50,86 \%$ of illegal goods came from consignment/postal service in 2016. The Indonesian FDA Jakarta Regional Office and The Regional Office of DGCE Jakarta implemented cooperation in monitoring the consignment of drugs and food through Pasar Baru Post Office since 2019. From the case study, this research aims to (1) conduct an analysis of regulatory changes that encourage the urgency of innovation in controlling consignments; and (2) perform an innovative analysis on the control of the consignments. The analysis proposes a qualitative method using field observation and interview with the officers from both institutions. Secondary data is also carried out by analyzing documents, regulations, and reports related to these activities. The tools used are the Business Model Canvas with three stages and analyzed nine elements. The result showed that the business model canvas used in this study creates a mutual understanding or perception among both institutions involved in the activity. The equal perception is an effective strategy before implementing other arrangements.
\end{abstract}

Keywords: The Indonesian FDA, Customs, Delivery Control, Business Model Canvas 


\section{INTRODUCTION}

The dark side of globalization in free trade or trade liberalization gives a rise to illicit trade. Criminals take advantage of this opportunity at the expense of consumer safety, undermining the competitiveness of official business actors, and reducing the government's credibility in the eyes of the public. Consumers and business actors depend on the role of the government in carrying out law enforcement efforts. Law enforcement efforts are needed to maintain consumer health and maintain a healthy business competition climate. The capacity of law enforcement institutions always needs to be evaluated and improved to carry out adequate inspection. The Organization for Economic Co-operation and Development (OECD) innovates ways to prevent the frequency of illegal shipments; and efforts to reduce illicit trade in the free trade zone. The sharp growth in the use of postal services as a method of shipping banned / illegal products has significantly impacted government institutions' capacity to detect and prohibit illegal products effectively. Selling products online adds to the complexity of the surveillance environment. Online trading tools increase commerce in consignments because consumers can buy goods directly from individual sellers. This lifestyle shift has affected the regulatory and policy framework and law enforcement, including the ability of customs and other relevant ministries/agencies to work to stop illicit trade (OECD, 2018).

The 2016 Annual Report of the Ministry of Finance showed that the entry of illegal goods was 6148 cases $(50.86 \%)$ of the 12087 cases found in the import sector from consignments/posts (Ministry of Finance, 2017). Based on data from the Indonesian FDA as a result of Pangea Operation IX in the customs area, it has carried out inspections in 5 (five) customs areas of DKI Jakarta Province, East Java Province, Central Java Province, Banten Province and resulted in 6414 packages that were inspected and found as many as 5917 packages (92\%) indicated that they contained illicit drugs and food (The Indonesian FDA, 2017). The shopping behavior of people who increasingly utilize ecommerce as part of advances in information technology is also seen to increase exploitation opportunities for illicit drug and food trade routes. The result of the BPS Survey on the 2019 E-Commerce Statistics states that out of 13,485 businesses, $27.85 \%$ sell food, beverages, and foodstuffs as the types of goods most sold, among other items in e-commerce. While cosmetics and toiletries were sold by $8.25 \%$ of business operators, medicines, including traditional medicines, were sold by $3.70 \%$ of e-commerce players. 
This data shows that the share of commodity sales in e-commerce in Indonesia related to medicine and food is around more than $35 \%$.

Meanwhile, on the global consumer side, based on The Digital 2020 Global Overview Report summarized by We Are Social and Hootsuite, finds that there are 4.5 billion internet users, $80 \%$ of which use the internet to make online purchases. Indonesia is the country in the first rank of e-commerce users, with $88 \%$ of active internet users. Total global spending in 2019 on food and personal care products amounted to the US \$ 168.8 billion, with an estimated $13 \%$ increase annually, the fifth-largest number of online purchases. Indonesian consumers spend on e-commerce on an average of US \$ 111 per purchase, or $2.9 \%$ of GDP per capita, which ranks fifth in world consumer spending than income. This picture below shows the tendency of consumers in Indonesia to be very active in online shopping and a potential e-commerce market for the world food and drug trade. The threat becomes clearer while looking at the data on Pangea Operation, carried out by The Indonesian FDA every year to fight the circulation of illicit pharmaceutical products that are mainly sold online (Figure 1). The insignificant result in reducing the number of online media as a medium for selling illicit pharmaceutical products shows that criminals have followed the trend of advancing information technology, seeing significant opportunities and small risks, and taking advantage of regulatory weaknesses.

Figure 1. E-commerce site blocked in Pangea Operation year 2015-2018

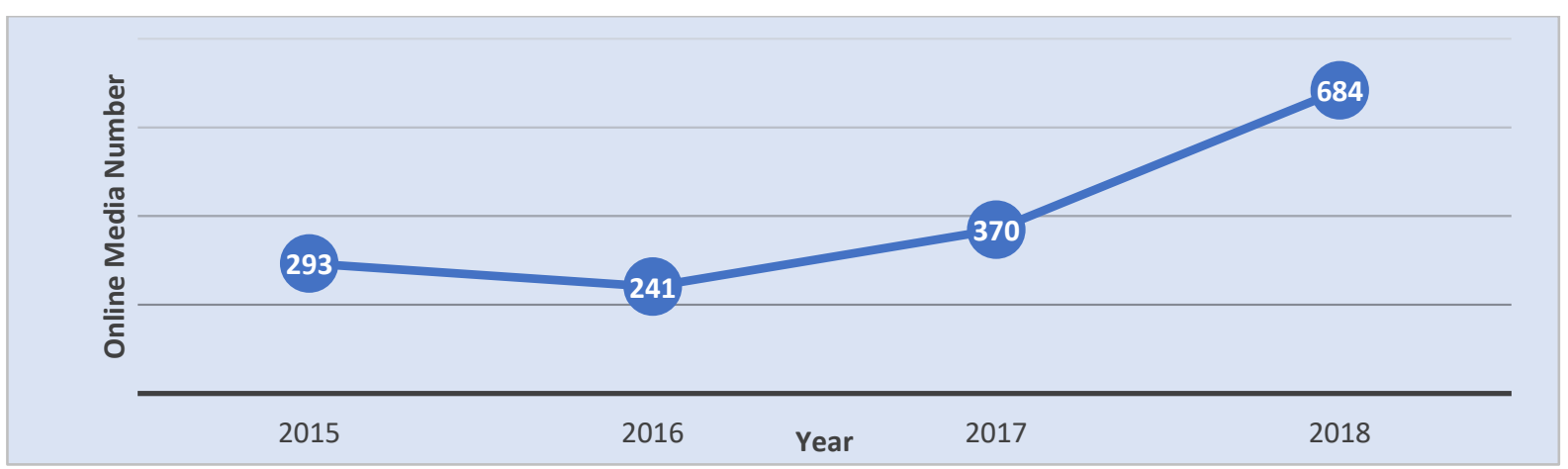

Source: The Indonesian FDA Annual Report, 2019 (compiled)

This research is essential to discern the synergy of institutional capacity between The Indonesian FDA and The Directorate General of Customs and Excise / DGCE in fighting the illicit trade in drugs and food. Therefore, it is necessary to conduct a study and analysis on an assessment of institutional capacity in innovation to prevent the frequency of illegal shipments. This study aims to (1) conduct an analysis of regulatory changes that encourage the urgency of innovation in controlling the entry of drugs and 
food through consignments, and (2) perform an innovative analysis on the control of the entry of drugs and foodstuffs through shipments by The Indonesian FDA and DGCE.

\section{LITERATURE REVIEW AND HYPOTHESIS DEVELOPMENT}

Some policies are taken by several countries to fight illegal trade through the importation of consignments, namely involving couriers and postal officers in detecting the entry of illegal products; developing best practices on the quality of data on the entry of consignments, and risk analysis techniques; expanding access, integration and stakeholder evaluation; involvement of e-commerce platform operators in detecting online transactions of prohibited products; and strengthening efforts in fighting illegal traffickers of illegal products online (OECD, 2018). Other studies have identified a large number of product shipments with large volumes/frequencies with small packages, through the delivery route in the seven surveyed countries, along with the rapid pace of e-commerce. As many as $62 \%$ of the confiscation of Customs and Excise Officers of illegal products is carried out on consignments, followed by air passengers and cargo by sea. Illicit or counterfeit products and drugs as the biggest threat occupy the same size in the 11 countries surveyed. In 184 countries, including Indonesia, cosmetic products and pharmaceutical products are among the top 11 counterfeit products often confiscated by Customs and Excise Officers. In the 2014 to 2016 development data, there is a significant development in counterfeit cosmetic products increased from $<5 \%$ to $>5 \%$ of the world trade in cosmetics, meanwhile counterfeit pharmaceutical products were still in the range of $<5 \%$ of the world trade in pharmaceutical products for the same period. Counterfeit products' market share is driven by consumer demand, who is aware that the product is counterfeit. For cosmetic products, it is very high, at $65.5 \%$ of the world's cosmetic market. However, for pharmaceutical products is relatively low, at $31.3 \%$ of the world pharmaceutical product market. This low market share is due to the awareness that counterfeit pharmaceutical products directly threaten consumers' health and safety. There are ten significant countries of origin for delivering counterfeit products: China, Hong Kong, United Arab Emirates, Turkey, Singapore, Thailand, India, Malaysia, Germany, and the United States (OECD/EUIP, 2019). The use of e-commerce as part of technological advances has increasingly changed people's shopping behavior, and it is considered a social vulnerability that leads to the threat of drug and food entry without distribution permits (Apriansyah, 2020). There has not been much research on innovation 
carried out by government agencies, especially in supervisory performance. Several studies found, particularly on the performance of The Indonesian FDA and DGCE, are still limited to the functions of disseminating information/extension services and licensing services. This study analyses the adoption process of food safety education innovations that have been carried out by the Indonesian FDA in the teacher and student environment (Kusumawardani \& Rohmah, 2018). Other research is about the automation of licensing services at the Customs and Excise Inspection and Service Office, which provides added value for convenience, acceleration, and legality of licensing (Fachrudin, 2018). Furthermore, this research requires to analyze supervisory innovations in the scope of the Indonesian FDA and DGCE duties, especially in developing research conducted by the OECD on illegal trade through the shipment import scheme.

Business models defined as the process of how an organization creates value and benefits from the value it creates in a sustainable manner (Rahmawan, 2017). The Business Model Canvas has been developed as a design thinking tool, including being adopted as the Government Model Canvas (Herwin, 2018). In government agencies, this tool is also developed as an Innovation Model Canvas. This tool is used to describe, analyze, and design models of tasks and functions, programs, and organizational activities. The business model describes the basis for an organization to create, capture, and provide value (Utomo, 2015). There are different definitions for the concept of a business model, yet these definitions can be identified and have something in common; namely, the business model must describe how the organization creates value for the beneficiaries; the business model should also describe how the organization generates benefits from its operations; business model construct must be externally oriented and explain the organization's relationship with various stakeholders around its strategic environment. A useful business model framework also describes the resources and capabilities of the organization. Thus, business models can also explain organizations' strategic decisions (Nenonen \& Storbacka, 2010). The management perspective uses the term strategy more often, while the information technology perspective uses the term business model. The business strategy, business model, and process model have the same purpose but lie at different business layers. Meanwhile, the strategic layer contains the vision, mission, and goals at the planning level. 
Figure 2. Business layer

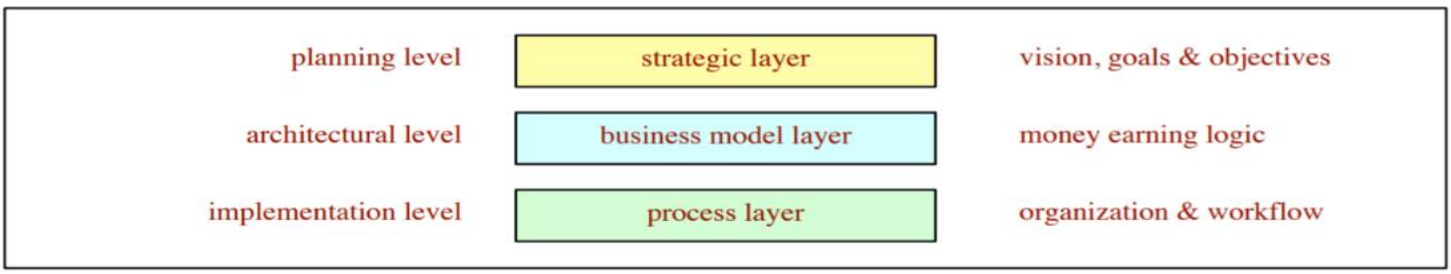

Source: Osterwalder, 2004

The business model layer contains the logic for profit is an architectural level. The process layer is an implementation level that contains work and organizational rules (Osterwalder, 2004). The Business Model Canvas has been widely adopted in the context of innovation and planning in government circles. It has nine essential elements in policy implementation (Osterwalder \& Pigneur, 2010). These elements are: 1) Public / Customer Segments, anyone is the target segment of the government in making policies so that they can feel the value built by the agency or organization; 2) Government Value I Value Propositions, values can be assigned to each Public Segment, so that policy implementation achieves the targets set and desired. Added value provided by programs / activities / services that can add added value to specific segments, can be in the form of solving problems faced or meeting needs; 3 ) Government Channels, channels required by government agencies to connect and provide value to the targeted public segments; 4) Government Relationship, strategy and implementation team that will be determined or agreed upon therefore the Government Channel could run smoothly in its strategy implementation; 5) Government Revenue / Income, the results obtained by agencies based on the value offered and received feedback / support from the public; 6) Government Key Resources, the primary resources required by agencies to be able to run programs / activities, in the form of physical, financial, intellectual, or human objects; 7) Government Key Activities, the main activities that must be carried out and monitored by the agency in order to proceed according to plan to provide added value and achieve the set targets; 8) Government Key Partners, important agency partners that are required to jointly carry out agency functions as determined and must be carried out in an effort to serve the Public Segment; 9) Government Budget Control, the main expenditure of agencies that must be monitored efficiently from the set budget (Herwin, 2018) (Utomo, 2015) (Osterwalder \& Pigneur, 2010). 


\section{RESEARCH METHODS}

This study used a qualitative approach with a case study method on the activities conducted by The Indonesian FDA Regional Jakarta Office. The analyzed activity is implementing cooperation between The Indonesian FDA and DGCE in monitoring the consignment of drugs and food. This activity is in the form of placing The Indonesian FDA-Civil Servant Investigators (PPNS) in the customs area related to the entry of drug and food products through a shipment scheme at the Pasar Baru Post Office, Jakarta. The primary data is carried out through field observations and interviews with the Indonesian FDA Regional Jakarta Office officers. Secondary data collection is carried out by analyzing planning documents, implementing, and evaluating these activities, laws, regulations, and other reports related to these activities.

The analysis tool used is a Business Model Canvas with three stages: 1) mapping the business model by determining nine essential elements in policy implementation; 2) analyzing the advantages, disadvantages, opportunities, and threats of each element of the existing business model. This analysis proposes identifying deficiencies in the existing business model concept to define future improvements or changes; 3 ) perfecting business models or making the prototypes of other business models to create a creative thinking process. However, the process must gather lots of ideas in forming a business model and provide one of the best ideas (Osterwalder and Pigneur, 2010). This Business Model Canvas is modified by using the theory used in the implementation of government policies.

\section{ANALYSIS AND DISCUSSION}

\subsection{The urgency of innovation in regulatory reform}

One of the threats that can occur in the entry route of drugs and food into Indonesia is the criminal act of importing drugs and food without a distribution permit into Indonesian territory. The distribution license itself in The Health Law and The Food Law is used as legitimacy in monitoring the security of pharmaceutical preparations and food safety. This crime has been regulated in The Health Law and The Food Law, which are the Indonesian FDA rules in conducting the inspection. Criminal sanctions for these acts in the form of imprisonment and fines have been clearly stated to provide a deterrent effect for the criminal. The criminals could be individual perpetrators or organized or corporate actors as well. Article 197 of the Health Law states that: 
Anyone who deliberately produces or distributes pharmaceutical preparations and / or medical devices that do not have a distribution permit as referred to in Article 106 paragraph (1) shall be subject to imprisonment of up to 15 (fifteen) years and a maximum fine of IDR 1,500,000,000,- (one billion five hundred millions rupiah).

Article 142 of the Food Law states:

Food Business Actors who deliberately do not have a distribution permit for any Processed Food made in the country or imported to be traded in retail packaging as intended in Article 91 paragraph (1) shall be punished with imprisonment of 2 (two) years or a maximum fine. a lot of IDR 4,000,000,000,- (four billions rupiah).

Both laws also emphasize that corporate criminals can be given the weighting of criminal sanctions 3 (three) times from the criminal fines of individual criminal sanctions. The penalty shows the state's seriousness in protecting people from drugs and food that endanger health while maintaining economic stability in the aspects of health and food self-sufficiency. So, policies and regulations under the law must always refer to these objectives and not contradict each other.

The XV Economic Policy Package has pushed for adjustments to existing regulations at the Indonesian FDA to support the shift of drug and food commodities to the post border (Coordinating Ministry for Economy, 2017). This adjustment is made by revising the Chief of Indonesian FDA Regulation No. 4 of 2017, and Chief of Indonesian FDA Regulation No. 5 of 2017 became Indonesian FDA Regulation No. 29 of 2017 and Indonesian FDA Regulation No. 30 of 2017. Some of the changes that impact the supervisory business process are regulated in the chapter on exceptions and Inspection (Table 1).

Table 1. The Changes in The Supervisory Business Process

\begin{tabular}{|c|c|c|c|}
\hline No. & Chapter & $\begin{array}{c}\text { Importation of Drug \& Food } \\
\text { Raw Materials }\end{array}$ & $\begin{array}{l}\text { Importation of Medicinal \& } \\
\text { Food Products }\end{array}$ \\
\hline 1. & Exception & $\begin{array}{l}\text { Regulate the exclusion of Drug } \\
\text { and Food ingredients without } \\
\text { the entry permit for the } \\
\text { distribution purposes: research, } \\
\text { product development and / or } \\
\text { science (research). }\end{array}$ & $\begin{array}{l}\text { Regulate exceptions for Drugs and } \\
\text { Food without a distribution permit } \\
\text { that enter for the following } \\
\text { purposes: a. sample for } \\
\text { registration; b. research, product } \\
\text { development and/or science } \\
\text { (research); c. donation; d. } \\
\text { exhibitions for Traditional } \\
\text { Medicines, Cosmetics, Health } \\
\text { Supplements and Processed Food; }\end{array}$ \\
\hline
\end{tabular}


e. Medicines for urgent national interests (Extraordinary Events /KLB, epidemics, and disasters); and f. own/personal use for Medicines, Biological Products, Traditional Medicines, Cosmetics, Health Supplements, and Processed Food.

The importation is through a special pathway mechanism (Special Access Scheme (SAS)). The provisions on SAS will be regulated in the regulations for the entry of Drugs and Food through a special route (SAS).

The importation is made through shipping/transportation services.

Must meet the following conditions: a. not for sale; and / or b. in limited quantities as needed.
The importation is through a special access scheme (Special Access Scheme) and donations. Except for the purposes of its own use, SAS applications are submitted to the Chief of The Indonesian FDA. The provisions regarding SAS and donations will be regulated in the regulations for the entry of Drugs and Food through a special channel (Special Access Scheme) and donation.

The importation can be made through: a. services delivery/transportation; or b. passenger's luggage.

For sample registration, exhibition, research, product development, science (research), and / or own / personal use must meet the requirements as the following: a. not for sale; and b. in limited number.

DGCE supervises drugs and foods put in territory Indonesia for personal use by using the form "Notification of the Entry of Drugs and Food by Passengers for Personal Purposes" and the form "Notification of the Entry of Drugs and Food through Transport Services for Personal Purposes." If the results of an inspection by DGCE find that Drugs and Food are suspected to be not in accordance with the provisions of the regulations, then DGCE will coordinate with The Indonesian FDA. 


\begin{tabular}{|c|c|c|}
\hline 2. Inspection & $\begin{array}{l}\text { Inspection is carried out on } \\
\text { products and facilities to } \\
\text { ensure: a. the physical } \\
\text { suitability of drug and food } \\
\text { ingredients with data on entry } \\
\text { documents; and b. compliance } \\
\text { with regulations legislation. } \\
\text { Inspection can be carried out } \\
\text { based on a risk analysis. } \\
\text { Risk analysis can be carried out } \\
\text { based on data on the realization } \\
\text { of drug and food entry sent } \\
\text { through the Indonesia National } \\
\text { Single Window portal. } \\
\text { Inspection is carried out in } \\
\text { coordination with related } \\
\text { Ministries/Agencies. }\end{array}$ & $\begin{array}{l}\text { Inspection is carried out on } \\
\text { products and facilities to ensure: a. } \\
\text { physical suitability of Drugs and } \\
\text { Food with data on entry } \\
\text { documents; and b. compliance } \\
\text { with regulations legislation. } \\
\text { Inspection can be carried out based } \\
\text { on a risk analysis. } \\
\text { Risk analysis can be carried out } \\
\text { based on data on the realization of } \\
\text { drug and food entry sent through } \\
\text { the Indonesia National Single } \\
\text { Window portal. } \\
\text { Inspection is carried out in } \\
\text { coordination with related } \\
\text { Ministries/Agencies. }\end{array}$ \\
\hline
\end{tabular}

Source: The Indonesian FDA Regulations, compiled

In the new regulations, there are several things that are required to be highlighted to the extent of the innovation in the supervisory business process. The amendment regulates the exclusion of drug and food entry without distribution authorization (import letter) for special and individual purposes. The import of drugs and food for special and individual purposes is carried out through an importation scheme for consignments or passenger luggage. Prohibitions and restrictions are placed on the designation of the goods, not for sale and in limited quantities as required. Inspection is carried out by encouraging the application of risk analysis, as well as in a cooperation between The Indonesian FDA and DGCE. However, this cooperation provides space for creating innovation in drug and food control to be more effective. Moreover, the strategy will maximize cooperation among both government agencies. The innovation is understandable as a series of changes to the complexity of a system, not only physically, but also in the social context within the organization (Wicaksono, 2018). Innovations that can be applied to the public sector are also expressed as the creation and implementation of new processes, products, services, and methods that result in significant, efficient, effective, and quality improvements (Albury, 2005). Public sector innovation that must be taken seriously is also said to be an idea that can be applied to the public sector, and the idea is entirely new or partly new and useful (Mulgan, 2010). Collaboration between these two government agencies produces innovations that can answer opportunities and challenges for the circulation of illegal drugs and food (Bommert, 2010). The limited 
authority of The Indonesian FDA in verifying the conformity of documents to the contents of the shipment is bridged by DGCE through the Pasar Baru Customs Office.

Furthermore, reviewing The Minister of Finance Regulation on individual import schemes, namely consignments, it is necessary to pay attention prior to implement the innovation. It should be realized beforehand that the potential threat of entry of illegal drugs and food leads to abuse of this scheme driven by advances in information technology and transportation, as well as other social vulnerabilities that accompanied (Apriansyah, 2020). Yet, it is clear that illegal products transported under the cargo/container scheme still dominate. However, in terms of the number of seizures, the trade in illegal products in parcels is increasing to be a significant problem in terms of law enforcement (OECD, 2018). The scheme for importing consignments can be seen in Figure 3. In the scheme of importing consignments, there is a risk analysis that must be considered in a customs inspection. This risk analysis is based on the profile of incoming drugs and foods as well as documents and profiles of the sender/recipient. Thus, the role of The Indonesian FDA is very crucial in providing more accurate information for the profile of drugs and foods, including the clarity of limiting the amount/volume that is suitable for individual interests based on considerations of consumer needs and/or health. Meanwhile, some information submitted in the form by the sender or recipient act as the source of data and information. The data is being analyzed jointly between The Indonesian FDA with DGCE Intelligence in foreseeing the facts and trends of the threat of drug and food entry without a distribution permit. The postal operators and courier services (PJT) are currently very advanced in the use of information technology, yet the use of information technology has still not been used in gathering information and analysis. This is indeed a global weakness that can be corrected immediately through innovative steps (OECD, 2018). The information provided as manifest in the cargo scheme is not found in the freight scheme. The information available is still on paper and is not available electronically. Besides, postal companies provide door-to-door tracking services in which can be traced electronically. This weakness is classified as the vulnerability in the use of information technology as a track and trace system, as well as trend analysis to prevent the entry of drugs and food without prior permission. 
Figure 3. Consignment Importation Scheme (compiled)

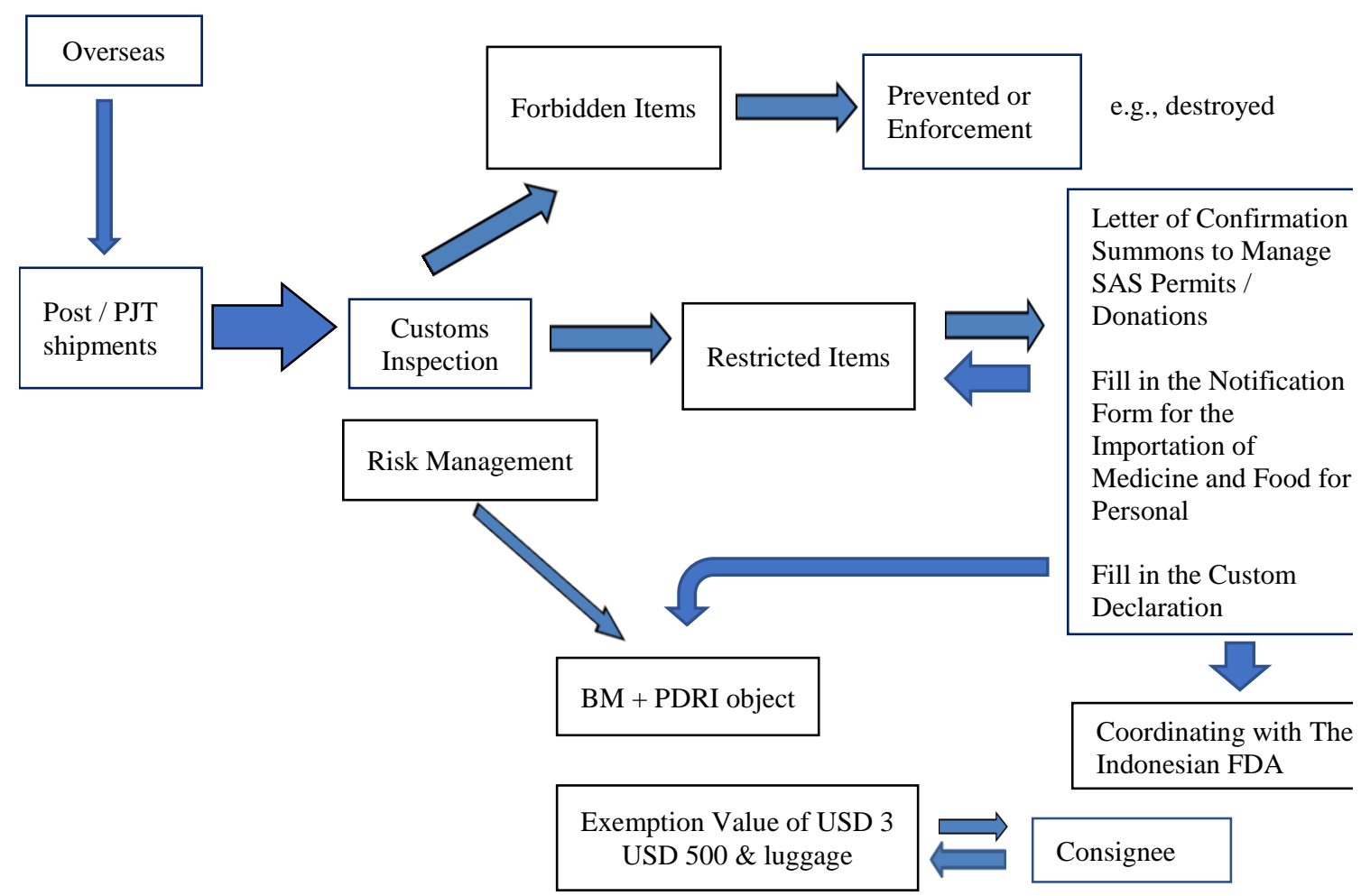

\subsection{Innovation Canvas Analysis}

The strategy of The Indonesian FDA Investigators (Civil Servant Investigator/PPNS) placement in the customs area provides data required in the research. It is a strategic collaboration between The Indonesian FDA Jakarta Regional Office and the Regional Office of DGCE Jakarta then arranged a framework of nine elements of a business model canvas. The model is shown in Figure 4 below.

Figure 4. Business Model Canvas of Delivery Control (analysis)

\begin{tabular}{|c|c|c|c|c|c|}
\hline Covermment Key Parthers $\theta$ & Govemment Key Activites & Covernment $\mathrm{V}$ & î & Covernment Relationuhios $\boldsymbol{V}$ & Molic Seoments \\
\hline \multirow[t]{2}{*}{$\begin{array}{l}\text { Regional Office of } \\
\text { DGCE DKI Jakarta } \\
\text { Pasas Bary Post Office }\end{array}$} & $\begin{array}{l}\text { - Signing of leadership } \\
\text { commitment } \\
\text { - Drug \& Food } \\
\text { surveillance posts } \\
\text { - Joint inspection } \\
\text { - Intelligence } \\
\text { information exchange }\end{array}$ & \multirow{2}{*}{\multicolumn{2}{|c|}{$\begin{array}{l}\text { Solution for the gap } \\
\text { in supervision \& } \\
\text { public education } \\
\text { with added value: } \\
\text { - direct education / } \\
\text { information } \\
\text { - integrated } \\
\text { supervision } \\
\text { - more upstream } \\
\text { supervision } \\
\text { - responsive as an } \\
\text { early detection \& } \\
\text { early warning } \\
\text { system }\end{array}$}} & $\begin{array}{l}\text { - Consultation on the } \\
\text { prohibition and } \\
\text { restriction of Drugs \& } \\
\text { Food } \\
\text { - Statement of legality } \\
\& \text { use of goods }\end{array}$ & \multirow[t]{2}{*}{$\begin{array}{l}\text { - Community as: } \\
\text { - Patient } \\
\text { - Online buyers } \\
\text { - Disaster donor } \\
\text { - Researcher } \\
\text { - Drug \& Food business } \\
\text { actors }\end{array}$} \\
\hline & \begin{tabular}{|l|} 
- PPNS \\
- Surveillance \\
investigation devices \\
- Current year's budget
\end{tabular} & & & \begin{tabular}{|l|} 
- Email \\
- Whats app \\
- Online form (Google \\
form) \\
- Written form
\end{tabular} & \\
\hline Govermment Budpet Contral & & 20 & \multicolumn{3}{|c|}{ Government inceme - Source } \\
\hline $\begin{array}{l}\text { - Travel expense } \\
\text { - Investigationfees }\end{array}$ & & & \multicolumn{3}{|c|}{$\begin{array}{l}\text { - Increasing public awareness } \\
\text { - Added monitoring sensitivity } \\
\text { - Strengthening prevention efforts } \\
\text { - Increasing the solidity of agency cooperation }\end{array}$} \\
\hline
\end{tabular}


Public Segment. This segment describes several segments of society that focus on service and inspection of The Indonesian FDA Jakarta Regional Office and The Regional Office of DGCE Jakarta. They are the people classify as patients, online buyers, and donors, research professionals, and drug and food business actors. The patients consist of those who require medicine or special food to support medication, which is not available in Indonesia. The online buyers usually are customers whose lifestyles or beliefs over imported drug and food products. The donors are a global community that contributes medicines and food as an aid for natural disasters or extraordinary condition occurs in Indonesia. Research professionals could be academic/non-academic research institutions or professionals who require drug and food products to be used in their scientific or product development research. Drug and food business actors are entrepreneurs doing business in the field of drugs and food that import products from abroad to be used as samples in exhibitions or complete the registration requirements of the Indonesian FDA.

This element shows the existing advantages, namely the breadth of the people who can get value from the implementation of policies, from the communities, professionals, and entrepreneurs. The weakness that exists is that it does not rule out other people as representatives who represent each segment of society. The opportunities in selecting this segment will broadly show first-hand the collaborative performance between the Indonesian FDA and DGCE, as well as increase public confidence in the service system and inspection. The possible threat comes from the dissatisfied consignees that cause of the unclear explanation or another communication barrier.

In this broad community segmentation, several things are essential to be considered related to the dimensions/role of society, community characteristics, and community needs (Rahmawan, 2017). This further adapted to the drug and food control environment. This community profile analysis will make it easier to prepare every aspect of monitoring resources and strategies. Threats may arise can also be overcome by increasing the competence of human resources in direct interaction with the community, as well as with more detailed regulatory resources.

Government Values. The values built in this activity mean to provide solutions to fill the gap in public education and inspection. This is a counterweight to the policy objectives that underlie to maintain the competitiveness of local products and protect the community from illicit imported drugs and food. These values are also actualized with an 
innovative approach that combines The Indonesian FDA and DGCE Inspection in an integrated manner, creating an inversion pattern with the upstream inspection at the entrance to the import of consignments, as well as responsive efforts for early warning and detection.

The advantages of this element provide a balance between inspection (law enforcement action) and increasing community awareness through public education. There is no shortage of value to be achieved according to policy objectives. Nonetheless, the opportunities from this element will increase public understanding of the quality and safety of imported drugs and foods, and also provide a deterrent effect on criminals. The threat that may arise in this segment will be protests from the public/criminals who suffer loss from this strategy. The added value can be generated, among others, from several measures of novelty or known as a newness, which is stated by Osterwalder \& Pigneur, (2010), because of new activities. This includes performance because it shows collaborative performance, risk reduction due to reducing risks to the community, and access due to affordability of services and inspection to the community.

Government Channels. The channels used to convey values in this activity while they are conveyed to the public are through face-to-face or direct services, written forms, email, messages (WhatsApp messenger), and online forms (Google Form). The function of the channel in this activity includes two functions amongst several functions, as stated by Osterwalder \& Pigneur, (2010). These channels purpose to increase public awareness and provide support for the community to avoid illicit drugs and food. The use of faceto-face or direct consultation services and written forms is carried out until the period before the pandemic (third week of March 2020). Since the end of March 2020, face-toface services have been eliminated and replaced by an online system. The consignee fills out forms and makes online consultation if required. The Indonesian FDA, as the provider of consultation service and verification of consignment documents, sets a time limit for maintaining service quality, varying from 1 to 5 working days. The use of online services is a solution when there is an increase in the volume of shipments due to restrictions on the mobilization of people due to the pandemic.

In selecting this channel, it follows the AIDA framework (Attention, Interest, Desire, Action) from the community (Rahmawan, 2017). The channel has not directly attracted the attention of the public because almost all of them are engaged with e- 
channels stored on electronic devices. This channel development phase follows what Osterwalder\&Pigneur, (2010) said, the awareness, evaluation, purchase, delivery, and aftersales phases. These activities, which have been carried out within two years, are defined as the beginning of the evaluation phase because the channel has been introduced and utilized by the community, yet a more effective form is still being developed. The development of this phase shows positive vibes when this channel continues to be consistently implemented. It will get community support and become a media of confirmation for the community using delivery services to avoid illicit drugs and food.

The challenge of this element is the possibility of data fabrication since the verification process is based on submitted documents online. Despite the fact, this is an advantage because the physical inspection is ultimately carried out specifically on potential misuse or illicit products. Another challenge is the existence of a communication barrier in providing understanding to the consignee. Meanwhile, the advantage of choosing this channel is the sustainability of the service system that has changed due to the pandemic (Seetharaman, 2020). Electronic channels also facilitate the process of data collection and analysis.

Government Relationship. The strategy used in developing the relationship between The Indonesian FDA and DGCE with the community in this activity is the consultation of prohibited commodities. This develops a mutual relationship between the public requirement of the information about the legality and safety of drugs and food, as well as the profile of incoming drug and food data required by the government.

The government-public relationship category used in this activity is based on the interactions between individuals during the process of document verification about the consignment. The strengths in this category will develop a deeper connection emotionally between two parties. The presence of the Indonesian FDA represents the government in the midst of the society that uses delivery services. The challenge that may arise is the increase of demand for clarity of information from the officers on duty.

Government Revenue/Income. The value developed from the increase of public awareness that can be directly provided without bureaucratic boundaries. The combination of competencies and different jurisdictions between The Indonesian FDA and DGCE has become a strong point in prevention efforts due to the upstream inspection of drugs and foods through consignments and to increase the early warning and detection. 
This collaboration surely brings support and trust from the community because of the emphasis on the protection and acceleration of public services.

The advantages of this element have been able to represent existing values into performance targets that can be appreciated by the community. The weakness of this element was originally planning only specifically for online buyers of products from abroad so that the revenue target was only for prevention. Besides, the opportunities for this element can be seen when the Covid-19 pandemic occurs, the community increasingly needs other values, especially in the contribution of monitoring the distribution of donations. The threat that can occur if the need for donations does not meet the inspection requirements, discretionary action is required based on competence and professionalism. Specifically, the threat possibly comes from the verification and validation data process.

Government Key Resource. The key resource required is The Indonesian FDA Investigators. They are competent human resources in carrying out supervisory, preventive, and law enforcement duties. They also conduct surveillance and investigation that supervise the import of drugs and food.

The advantage of this element is that the activities have been adjusted, both financially and technically, since its implementation in 2019. However, the current regulation has been issued, and there is The Chief of Indonesian FDA Regulation No. 14/2020 and No. 15/2020, which provides further explanation of drugs and food consignment. Meanwhile, the opportunities exist if these activities are effective and provide an increase in public understanding. Furthermore, the possible threats arise to resource shortages on other assignments, as the population served increases.

Government Key Activities. This element describes the main activities of agencies that can lead to government values to be achieved. The MoU between The Indonesian FDA Jakarta Regional Office and The Regional Office of DGCE Jakarta and the joint inspection are activities that lead to the value of integrated inspection. Drug and food control are the activities that lead to a more comprehensive inspection. The intelligence information exchange is an activity that leads to responsiveness as early warning and detection.

The strength of this element is strong support and commitment by both institutions. The challenge in this element is no one decides who plays a major part in transform the 
information directly to the public about how the activity is held. Meanwhile, the opportunities that exist in this element are activities that can be developed by The Post Office involvement. However, the threat that may arise is the inconsistency between the regulations on drug and food control with The Indonesian Post regulations.

Government Key Partners. In this element, the key partners who are required to carry out activities are The Regional Office of DGCE Jakarta and The Head of Pasar Baru Post Office. The selection of the major partner in this activity was considered because the authority of the customs area is DGCE since The Pasar Baru Post Office involves monitoring consignment activities.

The advantage of this element is the easiness of organizing the activities of both key partners since their offices are under one roof. Moreover, it seems no visible deficiency is coming in accordance with the activities.

Government Budget Control. The budget seems to be controlled in the implementation of this activity is accommodation for the officers in Jakarta for carrying out activities outside the office and investigation costs if needed for surveillance activities. However, since this budget comes from performance-oriented state spending, value-driven should be an option to provide maximum protection value to the public.

The advantage of this element is that infrastructure costs can be reduced due to good cooperation with DGCE and The Indonesian Post. The weakness is the activity has not been specifically budgeted for The Indonesian FDA Jakarta Regional Office.

Upon completing the analysis on each block of the elements thoroughly, the research draws some improvements to the canvas business model. The improvements are made by taking an inventory of existing deficiencies and possible threats, then proposing solutions and preventive measures, as shown in Table 2.

Table 2. The BMC Proposed Based on Recent Practices

\begin{tabular}{|c|c|c|c|c|}
\hline No. & Element & Weakness & Threat & Improved BMC \\
\hline 1. & $\begin{array}{l}\text { Public } \\
\text { Segment }\end{array}$ & $\begin{array}{l}\text { It does not rule out } \\
\text { other groups as } \\
\text { representatives who } \\
\text { represent each } \\
\text { segment of society. }\end{array}$ & $\begin{array}{l}\text { The threat exists in the } \\
\text { public dissatisfaction } \\
\text { because of unclear } \\
\text { information or other } \\
\text { communication } \\
\text { barriers. }\end{array}$ & $\begin{array}{l}\text { Active communication } \\
\text { by key resources to } \\
\text { extent quality of public } \\
\text { service }\end{array}$ \\
\hline 2. & $\begin{array}{l}\text { Government } \\
\text { Values }\end{array}$ & N/A & $\begin{array}{l}\text { There are protests } \\
\text { from the } \\
\text { public/criminals who } \\
\text { suffer much loss from }\end{array}$ & $\begin{array}{l}\text { Propose a strategy } \\
\text { based on risk analysis } \\
\text { related to collaborative } \\
\text { performance. }\end{array}$ \\
\hline
\end{tabular}




\begin{tabular}{|c|c|c|c|c|}
\hline & & & $\begin{array}{l}\text { the strategy chosen by } \\
\text { the government. }\end{array}$ & \\
\hline 3. & $\begin{array}{l}\text { Government } \\
\text { Channels }\end{array}$ & $\begin{array}{l}\text { E-channels still don't } \\
\text { attract people's } \\
\text { attention. }\end{array}$ & $\begin{array}{l}\text { There is a possibility } \\
\text { of data fabrication } \\
\text { since the verification } \\
\text { process only based on } \\
\text { submitted documents } \\
\text { by online forms. }\end{array}$ & $\begin{array}{l}\text { Improve the available } \\
\text { e-channels to become } \\
\text { more user-friendly and } \\
\text { develop a system } \\
\text { whose capability in } \\
\text { detecting data } \\
\text { fabrication and other } \\
\text { security issues. }\end{array}$ \\
\hline 4. & $\begin{array}{l}\text { Government } \\
\text { Relationship }\end{array}$ & $\begin{array}{l}\text { It requires good } \\
\text { timing of service or } \\
\text { supervision because } \\
\text { it cannot be done } \\
\text { simultaneously on } \\
\text { many populations. }\end{array}$ & $\begin{array}{l}\text { There is an increase in } \\
\text { demand for clarity of } \\
\text { information from the } \\
\text { officers on duty. }\end{array}$ & $\begin{array}{l}\text { Relationship } \\
\text { evaluation and } \\
\text { continuous } \\
\text { coordination between } \\
\text { the government } \\
\text { involved. }\end{array}$ \\
\hline 5. & $\begin{array}{l}\text { Government } \\
\text { Revenue }\end{array}$ & $\begin{array}{l}\text { Initially, the planning } \\
\text { was only specific to } \\
\text { online buyers of } \\
\text { products from abroad } \\
\text { so that the revenue } \\
\text { target was only on } \\
\text { prevention efforts. }\end{array}$ & $\begin{array}{l}\text { It possibly comes } \\
\text { from the verification } \\
\text { and validation data } \\
\text { process. }\end{array}$ & $\begin{array}{l}\text { Develop a system } \\
\text { whose capability in } \\
\text { detecting data } \\
\text { fabrication to avoid } \\
\text { fraud attempts related } \\
\text { to government } \\
\text { revenue. }\end{array}$ \\
\hline 6. & $\begin{array}{l}\text { Government } \\
\text { Key } \\
\text { Resource }\end{array}$ & $\begin{array}{l}\text { There is still a lack of } \\
\text { detailed information } \\
\text { in regulations. }\end{array}$ & $\begin{array}{l}\text { The lack of resources } \\
\text { because of the } \\
\text { increasing number of } \\
\text { consignments. }\end{array}$ & $\begin{array}{l}\text { Implement effective e- } \\
\text { channel. }\end{array}$ \\
\hline 7. & $\begin{array}{l}\text { Government } \\
\text { Key } \\
\text { Activities }\end{array}$ & $\begin{array}{l}\text { No one decides who } \\
\text { plays a major part in } \\
\text { transforming the } \\
\text { information directly } \\
\text { to the public about } \\
\text { how the activity is } \\
\text { held. }\end{array}$ & $\begin{array}{lr}\text { There } & \text { are } \\
\text { inconsistencies } & \text { or } \\
\text { gaps between } & \text { the } \\
\text { regulations. } & \end{array}$ & $\begin{array}{l}\text { Effectively } \\
\text { coordination within } \\
\text { institutions who are } \\
\text { involved in the } \\
\text { collaboration. }\end{array}$ \\
\hline 8. & $\begin{array}{l}\text { Government } \\
\text { Key Partner }\end{array}$ & N/A & N/A & $\begin{array}{l}\text { Effectively } \\
\text { coordination within } \\
\text { institutions who are } \\
\text { involved in the } \\
\text { collaboration. }\end{array}$ \\
\hline 9. & $\begin{array}{l}\text { Government } \\
\text { Budget } \\
\text { Control }\end{array}$ & $\begin{array}{l}\text { This activity has not } \\
\text { been specifically } \\
\text { budgeted for The } \\
\text { Indonesian } \text { FDA } \\
\text { Jakarta Regional } \\
\text { Office }\end{array}$ & N/A & $\begin{array}{l}\text { Evaluate the on-going } \\
\text { activity to make an } \\
\text { effective budget } \\
\text { planning and control. }\end{array}$ \\
\hline
\end{tabular}

Therefore, create a mutual understanding or perception among both institutions involved in the activity is a priority. This part is essential to improve the quality of supervision and inspection related to consignment control (Apriansyah \& Munandar, 2019). 


\section{CONCLUSION}

Active communication and education are necessary to increase public awareness to protect the public against the misuse and abuse of drugs and food. This awareness is essential as a preventive action from consuming illicit drugs and food that endanger health. Collaboration between The Indonesian FDA Jakarta Regional Office and The Regional Office DGCE Jakarta is an innovation of canvas model supervision. The collaboration leaves some areas for improvement and evaluation. Improving the available e-channels is a priority strategy to increase public engagement and facilitate the general requirements of a user-friendly with a better security system. The monitoring and evaluation are other priority activities as part of a control system that proposes an effective strategy and budget planning. The business model canvas used in this study analyzes that create a mutual understanding or perception among both institutions involved in the activity is an effective strategy before other arrangements. This part is essential to improve the quality of supervision and inspection related to consignment or delivery control on drugs and food. If there is a discrepancy caused by a lack of understanding, then the direct warning and education follow immediately. However, if there is a suspicious act found, then law enforcement plays a part. The strategy contributes to providing necessary data to assess potential threats to the drug and food control. It will be useful as initial data to explore other strategies such as developing an alert system connected to surveillance system control.

\section{LIMITATIONS AND SUGGESTIONS}

Since the cooperation between The Indonesian FDA Jakarta Regional Office and The Regional Office of DGCE Jakarta has been just implemented, the research information is still limited. The qualitative methods could be enriched by adding or combining with numbers of quantitative data. However, this study seeks to find the meaning of symptoms and social interactions, especially in interviews and previous empirical data. This research has not yet reached post border surveillance with importation schemes through border society at land border areas, which may have other influential stakeholders. Moreover, this area of expertise leaves any space to improve. 


\section{ACKNOWLEDGEMENT}

We want to respect the Chief of Regional Office of DGCE Jakarta, the Chief of Pasar Baru DGCE Office, and the Chief of The Indonesian FDA Jakarta Regional Office for initiating the collaboration and coordination.

\section{REFERENCES}

Albury, D. (2005). Fostering Innovation in Public Services. Public Money and Management, 25(1), 51-56. DOI: https://doi.org/10.1111/j.1467-9302.2005.00450.x

Apriansyah, T. (2020). Analisa Collaborative Intelligence: Studi Kasus Pertukaran Informasi Intelijen Antara NADFC dan Ditjen Bea dan Cukai Pasca Kebijakan Pengawasan Post Border. Jakarta: Tesis, Universitas Indonesia.

Apriansyah, T., \& Munandar, A. I. (2019). Post Border Control Policy: Stakeholder Analysis Perspective. Customs Research and Analysis Journal, 1(1), 111-125.

Bommert, B. (2010). Collaborative Innovation in Public Sector. International Public and Management Review, 11 (1), 15-33.

Coordinating Ministry for Economy. (2017). Paket Kebijakan Ekonomi Tahap XV : Pengembangan Usaha Dan Daya Saing Penyedia Jasa Logistik Nasional. Jakarta: Team Writer.

Fachrudin, M. (2018). Otomasi Pelayanan Perizinan, Inovasi Pelayanan Publik Kantor Pengawasan dan Pelayanan Bea dan Cukai Tipe Madya Pabean C Kota Baru. Banten: Universitas Pamulang.

Herwin, M. (2018). Bersinergi dengan "Government Model Canvas" untuk Instansi Anda. Retrieved from https://coachmargetty.com/2018/05/11/bersinergi-dengangovernment-model-canvas-untuk-instansi-anda/

Kusumawardani, V., \& Rohmah, U. (2018). Adopsi Inovasi Penyuluhan Keamanan Pangan Badan Pengawas Obat dan Makanan Republik Indonesia. Jurnal Studi Komunikasi dan Media, 22(1), 45-64.

Ministry of Finance. (2017). Laporan Tahunan 2016: Membangun Kredibilitas Fiskal. Jakarta: Team Writer.

Mulgan, G. (2010). Ready or Not? Taking Innovation in the Public Sector Seriously. Retrieved from https://www.nesta.org.uk/report/ready-or-not-taking-innovation-inthe-public-sector-seriously/

Nenonen, S., \& Storbacka, K. (2010). Business model design: conceptualizing networked value co-creation. International Journal of Quality and Service Sciences, 2(1), 43 59. DOI 10.1108/17566691011026595

OECD. (2018). Governance Frameworks to Counter Illicit Trade. Paris: OECD Publishing. http://dx.doi.org/10.1787/9789264291652-en

OECD/EUIP. (2019). Trends in Trade in Counterfeit and Pirated Goods, Illicit Trade. Paris: OECD Publishing. https://doi.org/10.1787/g2g9f533-en

Osterwalder, A. (2004). The Business Model Ontology A Proposition in A Design Science Approach. Switzerland: Dissertation, Universite De Lausanne.

Osterwalder, A., \& Pigneur, Y. (2010). Business Model Generation: a Handbook for Visionaries, Game Changers, and Challangers. New Jersey, US: John Wiley \& Sons. 
Rahmawan, A. (2017). Panduan Lengkap Menyusun Rencana Bisnis Menggunakan Business Model Canvas. Retrieved from https://arryrahmawan.net/panduanbusiness-model-canvas/

Seetharaman, P. (2020). Business models shifts: Impact of Covid-19. International Journal of Information Management, 54, 102173. doi:10.1016/j.ijinfomgt.2020.1021

The Indonesian FDA. (2017). Laporan Tahunan . Jakarta: Team Writer.

Utomo, T. W. (2015). Memahami Organisasi dengan Kanvas Model [PowerPoint slides]. Retrieved from https://www.slideshare.net/triwidodowutomo/memahamiorganisasi-dengan-kanvas-model

Wicaksono, W. K. (2018). Tipologi Inovasi Sektor Publik Pada Tiga Program Inovatif Pemerintah Daerah Kota Surabaya (Tinjauan Reflektif terhadap Tiga Inovasi Pelayanan Publik Pemerintah Kota Surabaya Tahun 2018. Jurnal Manajemen Pelayanan Publik, 1(2), 196-206. 